\title{
Phenomenology of imagining and the pragmatics of fictional language
}

\author{
Michela Summa ${ }^{1}$ (D)
}

(c) The Author(s) 2020

\begin{abstract}
This paper focuses on the performative character of fictional language. While assuming that all speaking is a form of acting, it aims to shed light on the nature of fictional, and particularly literary, speech acts. To this aim, relevant input can be found in (a) the discussion of the ontological status of fictional entities and of their constitution and in (b) the inquiry into the interaction between author and receiver of a fictional work. Based on the critical assessment of different approaches in the debate on speech-act theory and literary fiction, the article first clarifies why the study of the performative character of fictional language cannot be reduced to either the discussion of the status of singular speech acts in the fiction or the inquiry into the pretend or unserious nature of fictional speech acts formulated by an author. While referring to Roman Ingarden's, Jean-Paul Sartre's, and Wolfgang Iser's work, it subsequently argues that such a performative character should be understood as a specific serious affordance-or appeal-to imagine and thus to participate in the constitution of the fictional world.
\end{abstract}

Keywords Fiction · Imagination · Speech-act theory $\cdot$ Phenomenology $\cdot$ Roman Ingarden · Wolfgang Iser · Jean-Paul Sartre

The current debate in the philosophy of fiction is largely devoted to questions concerning the ontological status of fictional entities and the epistemic status of fictional truths. While the former questions concern the kind of beings fictional entities are (e.g., if they are part of the ontology of the real world or of possible worlds, if they can be considered to be existent at all, etc.), the latter concern the epistemic status of fictional statement (e.g., whether these statements can be said to be true or false, whether we should qualify and restrict the context in which they can be said to be true or false, etc.). These areas of research are strictly connected: Answers to the question of whether and how fictional statements can be said to be true or false

Michela Summa

michela.summa@uni-wuerzburg.de

1 Institut für Philosophie, Universität Würzburg, Josef-Stangl-Platz 2, 97070 Würzburg, Germany

Published online: 09 July 2020 
largely depend on assumptions concerning the ontological status of fictional entities. ${ }^{1}$ Thereby, the ontology of fictional entities has been connected to the semantics of fictional language. Clearly, the analysis of fictional language is not limited to semantics and openly touches upon aspects of pragmatics. ${ }^{2}$ However, a closer inquiry into the connection between the ontology of fictional entities and the pragmatics of fictional language is still lacking. This article focuses on such a connection. More precisely, I first wish to discuss whether fictional language can be considered to have what J.L. Austin defines as a performative function. Secondly, having provided reasons for answering the previous question in the affirmative, I wish to investigate what the range of such performative function is, notably whether it concerns singular speech acts uttered in the fiction or whether it is further reaching, concerning not only what happens in the fiction, but also the impact the experience of fiction may have on our experience of reality.

In order to better clarify these questions, in Sect. 1, I introduce the aspects of speech-act theory that I consider to be relevant while addressing fictional language. In this regard, I present the reasons why, at variance with prevailing interpretations, the analysis of the performative character of fictional language cannot be reduced to either the discussion of the status of singular speech acts uttered in the fiction or to the assumption that an author's speech acts are pretend speech-acts. Instead, the performative character of fictional language should be reassessed on the basis of the ontology of fictional entities and the specific interaction between author and reader, which is required for their constitution. In support of this claim, in Sect. 2, I address Roman Ingarden's and Jean-Paul Sartre's inquiries into the ontology of fictional entities, notably focusing on their respective claims concerning the constitutive incompleteness and indeterminateness of such entities. In Sect. 3, I show in what sense such incompleteness and indeterminateness require us to consider the pragmatics of fictional language. Discussing Wolfgang Iser's remarks on the pragmatics of fictional language, which expand on Ingarden's ontology of fiction, and comparing them with Sartre's, I wish to shed light on the particular appellative character of fictional language. The suggestion I wish to make is that such an appellative structure shapes the relationship between the author and the receiver of a work of fiction, and that this relationship makes the constitution of fictional entities - their particular existence and objectivity-possible.

\section{Fictional language and performative utterances}

In J.L. Austin's lectures How to Do Things with Words? one finds a side remark on fictional language. The remark is formulated within the context of Austin's theory of infelicities, which is aimed to clarify how performative utterances-which do not describe anything, nor can be said to be true or false, but rather do something — can

\footnotetext{
1 Among the different positions on these questions, cf. Kroon and Voltolini (2018), Lewis (1978), Meinong (1904), Walton (1990), Recanati (2000), Thomasson (2008).

2 Cf. Locher and Jucker (2017), Pratt (1977).
} 
succeed or not. ${ }^{3}$ According to Austin, the conditions for the success of performative utterances (felicity conditions) are six, and can be organized in three groups including two conditions each. For our discussion, the third group of conditions, $\Gamma$. $1-2$, is particularly relevant. These conditions refer to the sincerity of the speaker: Speech acts are not successful if the speaker does not have the thoughts and feelings expressed in and through the speech act, and if as a consequence the conduct is inconsistent with what the speech act says. ${ }^{4}$ If such conditions are violated-for instance, if a promise is made without the intention to keep it-we have an abuse: The action is accomplished, but it is somehow corrupted or hollow. ${ }^{5}$ According to Austin's marginal remark, speech-acts uttered in a fictional context are special kinds of abuses:

a performative utterance will, for example, be in a peculiar way hollow or void if said by an actor on the stage, or if introduced in a poem, or spoken in soliloquy. This applies in similar manner to any and every utterance-a sea-change in special circumstances. Language in such circumstances is in special waysintelligibly - used not seriously, but in ways parasitic upon its normal useways which fall under the doctrine of the etiolations of language. All this we are excluding from consideration. ${ }^{6}$

Five implications of this short remark can help us pinpoint our problem. First, Austin is here considering performative utterances made in the fiction, i.e., utterances of a fictional character within the work of fiction (e.g., a promise or a bet made on stage: With their utterances, the characters are doing something in the fiction). Secondly, Austin says that, at least prima facie, if we consider these utterances as made by real persons (actors), then they should be considered as abuses, i.e., as a particular kind of infelicity due to insincerity. Thirdly, this particular case is, however, not to be actually equated with cases of insincerity: The utterances are produced in a context that is unserious as a whole. In other words, the actors, as real persons, do not express any insincere belief, emotion, or intention, nor do they intend to deceive anyone with their utterances. They speak as if they were the character in the fiction, but they do not expect anyone to take their utterances as serious in the real world. Fourthly, Austin observes that language in these cases is parasitic upon its normal or serious use. ${ }^{7}$ And fifthly, he claims that this does not only apply to performative utterances, but to all utterances in fiction, thus also to constative ones. These remarks show that the specificity of the performative function of language in fiction cannot be analyzed independently of an inquiry into the status of fictional entities

\footnotetext{
3 Austin (1962, pp. 5 f.; 1970).

4 Austin (1962, pp. 14-15).

5 Austin (1962, pp. 16 f.).

6 Austin (1962, p. 22).

7 Austin (1962, pp. 22, 104; 1970, p. 241). In a different way, this parasitism of fictional language is also emphasized by Ryle, when he observes that while pretending, what we say is meant to be taken in oratio obliqua; whereas while speaking seriously or in ingenuous performances what we say is meant to be taken in oratio recta. In this respect, pretending (as well as imagining) is a "sophisticated performance" or a "performance with a certain sort of complex description" (Ryle 2009, p. 236).
} 
and fictional contexts, as well as into the processes that constitute them. This, I believe, justifies Austin's laconic remark and the lack of a closer analysis of performatives in fiction.

Before returning to this point and asking whether this is the only sense in which we can understand the role of performatives in fictional language, let me mention why a further development in Austin's lectures is also important for the present inquiry. At the beginning of his lectures, Austin introduces a somehow dichotomous understanding of constative and performative utterances. According to it, all utterances should be classifiable as belonging to one class or the other. In support to this view, Austin contrasts for instance a bet and a description of a state of affair. However, Austin's attempt to find univocal, grammatical or semantic, criteria for the distinction between constative and performative speech acts fails, suggesting that such a dichotomous approach might not be appropriate after all. This failure can be considered to be productive in at least two respects. First, it shows that clarifying the performative character of utterances always requires the consideration of the particular situation in which the speech act is uttered. Secondly, due to the unsuccessful attempt to find univocal criteria defining constative and performative utterances, Austin eventually introduces the distinction between locutionary, illocutionary, and perlocutionary acts. ${ }^{8}$ This distinction is not dichotomous, nor does it imply that all speech acts can be univocally classified as belonging to one of these classes. It rather refers to different functions of speech acts, which potentially pertain to all utterances. Accordingly, the very same utterance-say "the window is open"-can be considered (a) as describing a state of affairs (locutionary act); (b) as having a force and doing something, for instance complaining (illocutionary act); and (c) as having effects and consequences on the addressee, for instance if the utterance is understood as a request to close the window (perlocutionary act).

In order to understand the status of literary language, this threefold distinction is significantly more helpful than the dichotomy of performative and constative utterances. In fact, a fictional text is generally not made exclusively of utterances one would typically recognize as belonging to the family of performatives. Rather, fictional works contain descriptions, explanations, reconstructions, etc. Certainly, as Austin remarks in the above quoted passage, fictional works can also include promises, commands, and bets made by some fictional character to some other fictional characters in the fictional context. But these are as unserious as everything else is said or written in the fiction; therefore, one may ask whether is there in fact anything particular to be said about them.

This allows me to make a step further in defining the scope of the present inquiry: If we are to ask about the specific performative character of fictional language, we should not primarily — and certainly not exclusively - investigate the nature of singular speech acts uttered in the fiction. What we should rather do, in order to find out whether there is a particular performative dimension in fictional language, is to investigate how fictional works as wholes can or should be considered to have a performative nature. In other words, we should ask whether language in a fictional

\footnotetext{
8 Austin (1962, pp. 94 f.).
} 
work, besides having a meaning, also does something. And, in case it is proved that fictional language does something, we should consider whether what it does has an impact on reality or remains confined within the domain of fiction. Accordingly, what I will focus on are not the speech acts uttered by actors or by fictional characters, but rather the kind of speech act authors perform while writing fictional works.

Similar questions are addressed by several thinkers dealing with speech acts and fiction. There is, however, no agreement on whether speech-act theory, and notably the discussion of performative utterances and illocutionary force, plays a role in fiction. John Searle contends that it does: Speech-act theory allows us to understand fictional language as pretend speech-act: "[A]n author of fiction pretends to perform illocutionary acts which he is not in fact performing." Composing a work of fiction, of course, the author does not aim to deceive anyone. Nonetheless, Searle claims, fictional language shares some features of non-deceptive pretense, inasmuch as authors of fiction engage in a performance as if they were really doing something. Searle seems to be somehow applying Austin's remark about the unseriousness-or, as I would rather say, the playfulness - of the speech-acts of an actor to the speech-act of an author. In this sense, fictional language would in fact do something, but this would not have any impact on reality, since the speech act is only feigned (or unserious). Yet, this is potentially misleading. As observed by Gérard Genette (2004), in a rather obvious sense, Searle is right: We would not argue that, writing "Once upon a time there lived in a certain village a little country girl...," Charles Perrault wanted to communicate a real event or to express his belief in the existence of Little Red Riding Hood. Yet, this does not exclude that, while making similar unserious utterances, authors of a fictional work are also doing something that we would not consider as unserious. Trying to clarify what they are doing is the aim of the present investigation.

Kendall Walton also addresses the question concerning the role of speech-act theory in the analysis of fiction, partly in response to Searle. He provocatively claims that "[s]peech-act theory is remarkably unhelpful in explaining what fiction is." 10 While recognizing that we can use speech-act theory in order to clarify or explain some features of literary fictions, Walton contends that speech-act theory does not play any substantial role for defining fiction. In response to Walton, and relying on his own theory of fiction inspired by Paul Grice's view on the utterer's intentions, ${ }^{11}$ Gregory Currie claims that: "[ $[\mathrm{t}] \mathrm{he}$ utterer of fiction [...] wants to get the audience to make-believe the proposition uttered."12 The "fictive illocutionary act," in this sense, is structurally similar to other speech acts—such as asserting, commanding, and requesting - but differs from these acts uttered in non-fictional contexts regarding the content of the utterer's intention.

In the following, I wish to argue that speech-act theory does play a role in defining what fiction is. Yet, unlike what might seem at first, my approach differs from

\footnotetext{
9 Searle (1975, p. 325).

10 Walton (1983, p. 78).

11 Currie (1990).

12 Currie (1986, p. 304).
} 
both Searle's and Currie's. At variance with Searle's claims, I will argue that we should not consider speech acts in fiction just as pretend illocutionary acts. Instead, if we consider the multilayered structure of fiction and the cooperation of author and reader and/or spectator in the constitution of fictional work, we need to recognize that works of fiction also operate following the structure of specific genuine or serious illocutionary acts. Accordingly, fiction has a particular performative character, which implies that it does something in a socially relevant context, primarily the context of interaction between author and reader. Furthermore, unlike Currie's view, my account is not primarily based on the analysis of the utterer's explicit intentions or aims. Instead, it is based on the ontological features of fictions and fictional entities and on the constitutive accomplishments of both authors and readers or spectators. While privileging an ontological approach and grounding it on the phenomenological analysis of the experience and constitution of fictions, this article investigates the intentional structures of our experience of fiction. Yet, with intentionality and intentional structures, I do not only mean the author's intentions to say or communicate something. Rather, as I endorse the phenomenological concept of intentionality, I refer to the aboutness of mental acts and of speech acts, which allows them to refer to and constitute fictional entities, making them what they are. Quite importantly, these are both the author's and the reader's intentions, and they are not a private matter, so that the constitution of fictions turns out to be a cooperative performative enterprise.

In this respect, the view I propose has several points of convergence with the one developed by Genette in response to Searle. Genette considers that speech-act theory can be fruitfully adopted in order to interpret fictional works, and notably the act performed by the writer. In particular, while conceding that one can take, in a specific sense, fictional utterances as a kind of pretense, he contends that this is not the whole story about fictional language. He then argues that, while making pretend utterances, authors also do something else-and something serious: They produce a work of fiction and appeal the readers to collaboratively imagine. ${ }^{13}$ Genette's argument is based on linguistic analyses and on his semiotic theory of narrative. He does not explicitly focus on the ontological status of fictional entities and on the connection between fictional entities, their intentional constitution, and the pragmatics of fiction.

\section{Ingarden and Sartre on the incompleteness and indeterminateness of fictional entities}

In order to clarify why the pragmatics of fictional language should be connected to the ontology of fictional entities, I now address some of Ingarden's and Sartre's observations on the ontology of fiction. There are several convergences and some divergences between the two thinkers. Among the convergences, one should mention in particular that both authors endorse an anti-psychologistic understanding of

13 Genette (2004). 
fiction and a discontinuity claim concerning the relation between perceiving and imagining. The divergences, however, are also important and they partly reverberate on their understanding of fiction. In particular, whereas Ingarden's approach to the question concerning the existence of fictional entities is based on identity and re-identification criteria, and only implicitly refers to intersubjectivity or sociality, Sartre's overall analysis of fiction is grounded on intersubjective, social, and dialectical structures. ${ }^{14}$

A joint assessment of the positions of these authors is nevertheless fruitful for two main reasons: First, they both emphasize the purely intentional nature of fictional entities; and secondly, they connect the specific mode of being of fictional entities to incompleteness, indeterminacy, and thus to relations of dependence. In this respect, the performative character of fictional language and thereby the sociality of the experience of fiction can only be understood in relation to such constitutive incompleteness and indeterminacy.

Ingarden develops his approach to the ontology of fictional entities in his book The Literary Work of Art. His first move is to clarify why the standard ontological distinction between ideal and real entities is not exhaustive, since it does not embrace all possible entities. Goethe's Faust, for instance, does not properly fall into either of the two realms. Faust is not to be considered ideal as the number 3 or Pythagoras's theorem are. In particular, Faust is not a-temporal or supra-temporal, but rather came into being at a determinate historical moment. Even if we may not understand what exactly the existence of Faust means, "[w]e are all agreed that Faust has existed from the moment of its formation." ${ }^{15}$ In this sense, fictional objects seem to come close to real objects. And yet, everyone would agree that Faust is no real entity either. This not only because we would not expect to meet him in the real world nor to find any testimony of his real existence, but more importantly because, even if a real person having all the characteristics and the story of Faust had existed, this person would not be Goethe's Faust. The existence of Faust, in other words, depends on creative acts. Accordingly, the criteria of identity for fictional objects are different from the criteria of identity for real objects: If the author of a work of fiction operates or approves some changes in the descriptions, and provided that such changes are not too far-reaching, we still take it as the same fictional entity, while this is not the case for real individuals. ${ }^{16}$

The embarrassment we experience while trying to classify fictional entities, according to Ingarden, is only due to the assumption that there are only two realms of being: ideal and real. In fact, this gives us reasons to question the exhaustiveness of such a distinction and to consider fictional entities as belonging to a third sui

\footnotetext{
14 Cf. Bonnemann (2007, pp. 153-160).

15 Ingarden (1973b, p. 10).

16 Ingarden (1973b, p. 11). It should be emphasized that, as Ingarden remarks, there are limits to these alterations: First, they cannot be too far-reaching, which means that they cannot concern some crucial or defining moments of the narrative; secondly, everyone can make these changes in order for the fictional object to be preserved. Eventually, only the author-or possibly the publisher-can. For a discussion of the identity conditions of fictional objects, see Thomasson (2008).
} 
generis realm of being: the realm of "purely intentional being." ${ }^{17}$ What distinguishes the entities belonging to this realm? Ingarden considers the ontology of fictional entities as an ontology of dependence: Fictional entities depend on the fictional works they are part of; on the creative acts of authors producing these works; and on competent receivers of these works. Ingarden notably provides a complex, foundational or stratified, account of fictional works, on which fictional entities depend. He notably distinguishes the following four levels in fictional works:

(a) The stratum of linguistic sound formations, including all the material—written or oral—signs and sounds that form a literary object. This stratum includes not only words and sentences, but also the metric and prosodic dimension, rhythm, melody, the organization of the text in paragraphs, etc. ${ }^{18}$

(b) The stratum of the meaning units, that is to say, what is signified by linguistic expressions. This stratum ranges from individual essences (meanings of proper names) to more complex states of affairs or processes in temporal development (meanings of judgments, of entire paragraphs or chapters). ${ }^{19}$

(c) The stratum of the represented objects, which are all the fictional entities (characters, episodes, events, states of affairs, etc.) that are presented in the fiction. ${ }^{20}$

(d) The stratum of schematized aspects - the aspects and the modes of appearancein and through which characters, states of affairs, situations, stories, etc. are presented in a literary work. This already makes clear that what is presented in a literary work is always presented in and through a certain description embracing some of its aspects and properties, and from a certain perspective. ${ }^{21}$

This stratified view expands on the topic of authorial dependence. Saying that fictional entities are produced by someone at a given moment in time and can be modified-under certain conditions-only by their authors, implies that such entities are not independent: They need authors, their intentional acts, in order to come to existence. Moreover, the previous distinction of layers making up fictional works also indicates that fictional entities need a material support and a corresponding meaningful formation in order to come to and be kept in existence. ${ }^{22}$ Finally, these entities also need the activity of receivers in order to get concreteness and, again, to be maintained in existence. These dependence relations importantly underlie the ontological specificity of fictional entities as distinguished from both ideal and real entities. ${ }^{23}$ Further elements for the distinction between real and fictional entities are

\footnotetext{
17 Ingarden (1973b, pp. 7-8).

18 Ingarden (1973b, pp. 34 f.).

19 Ingarden (1973b, pp. 62 f.).

20 Ingarden (1973b, pp. 217 f.).

21 Ingarden (1973b, pp. 255 f.).

22 As we will see in the following, this second remark implies that fictional entities are not only dependent on the activity of the author, but also on the activity of the reader. Yet, in order to understand this claim, we need to address some other features of fictional entities and, more precisely, consider the pragmatics of fictional language.

23 Cf. Thomasson (2008).
} 
to be drawn from the analysis of the two latter strata in Ingarden's distinction. To be sure, real entities are also given in and through aspects. Both perception and description are in this sense generally incomplete insofar as they cannot grasp all of the aspects of a given object at once: We always intend objects from a certain perspective, and we describe them in a certain way and not in another. This implies that our experience of real objects entails moments of indeterminacy. But can we say that the situation is fully identical for real and fictional objects? The answer is no: In fact, the indeterminacy of real objects is a determinable indeterminacy. When we have to do with real objects, we have the possibility to explore them, to add more aspects to the original aspectual presentation, to possibly correct some wrong expectations, and to determine them for what they are. The indeterminacy in the presentation of a real object, in other words, is cognitive or indeterminacy for us. Conversely, the indeterminacy of a fictional object is ontological or indeterminacy in itself. If nothing is said about a certain object in a fictional work-one of Ingarden's examples is the color of the senator's eyes in The Buddenbrooks - then this aspect is in itself just empty and indeterminate. It would not make sense to look for a univocal determination of something that is not mentioned in a fictional work. Thus, we can make no claim concerning the truth or falseness of any statement aimed at determining such indeterminacy, nor can we take one imaginary representation aimed to fulfill such indeterminacy as more appropriate than others. Ingarden formulates the difference as follows:

Univocal, universal determination means that in its total essence [Sosein] a real object cannot have any spots where in itself it would not be totally determined, i.e., either by A or by non-A, and indeed where it would not be so determined that, as long as A was its determination in a given respect, it could not, at the same time, in the same respect, be non-A. To put it briefly: Its essence does not show any spots of indeterminacy. This is part of the intuitively apprehendable essence of real objects and it would be absurd to claim the contrary. ${ }^{24}$

Different from real objects, fictional objects have indefinite and non-determinable spots of indeterminacy, for which it is just undecidable whether they are A or non-A. This already brings to the fore the need to consider the relation between the constitutive indeterminacy of the fictional object and the cognizing activity of the addressee of a fictional work, that is to say, of the reader in the case of literature. Ingarden further clarifies this point by investigating how names refer to, respectively, real and fictional objects. In both cases, naming an object entails the reference to a limitless number of individual determinations of one and the same object and this to a virtually limitless cognitive process of explication. However, even though we can never know how a given real individual object designated by a name is determined in every respect, "this does not mean that in itself it is not unequivocally, universally determined; it merely means that in this kind of cognition, which proceeds along the paths of apprehending the object's individual determinants, it is possible, in accord

${ }^{24}$ Ingarden (1973b, p. 246). 
with the object's essence, to apprehend it in a finite series of cognitive operations only inadequately." ${ }^{25}$ With fictional entities, the situation is different:

If, e.g., a story begins with the sentence: 'An old man was sitting at a table,' etc., it is clear that the represented 'table' is indeed a 'table' and not, for example, a 'chair'; but whether it is made of wood or iron, is four-legged or threelegged, etc., is left quite unsaid and therefore-this being a purely intentional object-not determined. The material of its composition is altogether unqualified, although it must be some material. Thus, in the given object, its qualification is totally absent: There is an 'empty' spot here, a 'spot of indeterminacy.' As we have said, such empty spots are impossible in the case of a real object. At most, the material may, for example, be unknown. ${ }^{26}$

This ontological incompleteness requires a corresponding activity by the readers: the activity of fulfilling the spots of indeterminacy, while maintaining the awareness that such indeterminacy cannot be removed once and for all. Ingarden introduces this activity already in his ontological book, ${ }^{27}$ and he further explores it in the epistemological work On the Knowledge of a Literary Work of Art. ${ }^{28}$ He thereby characterizes the activity of concretization and actualization of the work of literature, which is precisely obtained by means of the intuitive, imaginative, fulfillment of the gaps in the presentation of literary objects. The receiver's activity of fulfilling indeterminacies through actualization and concretization-even without possibly making any legitimate claim as to the univocal and exclusive rightness of the fulfillment-is as necessary for the constitution of a fictional entity as the activity of the author who presents the object under a certain description. ${ }^{29}$ As I wish to argue, these remarks at least implicitly hint at the performative power of the literary work. Before discussing why, let us consider how Sartre, in his early works on imagination and literature, conceives of the ontological status of the fictional object.

The main convergence between Sartre and Ingarden hinges on the claim that imaginary and fictional objects are intentional formations and that they have as such a specific kind of existence. What distinguishes Sartre's position and marks its difference from Ingarden's is the explicitly dialectical-intersubjective understanding of how fictional objects are constituted. The way such a dialectics is actualized also marks the distinction between the irreality of imaginary objects and that of fictional objects. Dialectics, and notably the dynamics inaugurated by the moment of negation, is at work in both cases. Yet, what one merely imagines is only the result of reality negating imaginative acts or subjective phantasies, which are eventually products of pure spontaneity. Constituting fictional entities adds a further movement of negation, which makes of such entities not only the product of my individual phantasies, but also objects for others.

\footnotetext{
25 Ingarden (1973b, p. 247).

26 Ingarden (1973b, p. 249).

27 Ingarden (1973b, pp. 331 f.).

28 Ingarden (1973a, pp. 19 f.).

29 Ingarden (1973a, pp. 37 f.).
} 
In The Imaginary, Sartre addresses different forms of imaginative experiences and the mode of givenness and the constitution of the respective intentional correlates. He considers mental images (images mentales) at the end of a chain including phenomena such as physical images, portraits, faces on fire, spots on walls, rocks in human forms, hypnagogic images, and mental images. This chain is characterized by a progressive impoverishment of matter: Mental imagery is located at the very end of this chain precisely because matter disappears and the imagistic representation is the mere product of the spontaneity of consciousness or of an act of irrealization. ${ }^{30}$ Importantly, for Sartre, arguing that imaginary objects are irreal—or products of irrealizing acts-does not mean to claim that they do not exist, for we should not confuse reality with existence. The qualification of irreality notably defines the specific mode of existence of fictional entities. ${ }^{31}$ The existence of imaginary objects as products of mental imagery, however, is clearly unstable. As Husserl would say, these objects have a protean character. They are constitutively intermittent and there is no possibility to make them stable or re-identify them through identity criteria. ${ }^{32}$ Also, and most importantly, my own phantasies are only accessible to me; they are objects of my spontaneity. This is the main reason why the concept of imaginary object should be taken very broadly, that is to say, as mere correlate of a negating and spontaneous act of consciousness. This is not strictly speaking objectivity, which would include some criteria for identity and, most importantly, recognizability by other subjects. And, precisely in this respect, we come to the difference between imaginary and fictional objects. The latter are also products of irrealization. Yet, unlike the former, they are not only the product of my spontaneity and they are neither intermittent nor unstable. Instead, they are objects to which different individuals can refer and they are subject to identity criteria. When we speak of fictional objects, we mean object in a much stronger sense than when we speak of imaginary objects.

This difference and the kind of objectivity pertaining to fictional entities is further investigated in What is Literature? Here, Sartre describes the dialectical process in and through which literary works and the fictional entities, stories, episodes, situations, etc. that compose them are constituted. Sartre builds his argument in particular around the title question of the second essay: "Why Write?". Answers considering literature as a flight or a means of conquering are not satisfactory, since they do not explain why one decides precisely to write and not to do something else in order to pursue the same aim. Sartre's answer to this question is rather complex and based on the distinction between perceiving and creating. Whereas perceiving is "unveiling" something that is given to us-it is an activity, then, in which we are a medium, "detectors" of being ${ }^{33}$ —creative activities express our need to feel

\footnotetext{
30 Sartre (2004, pp. 17 f.).

31 Sartre (2004, p. 63); cf. Summa (2019).

32 Husserl (2005, pp. 63 f.).

33 Sartre (1966, p. 39). The translation is modified, the English texts wrongly translates detecteurs with "directors." Also, I believe that "unveiling" is a better choice than "revealing" in order to translate dévoiler.
} 
necessary with regard to the world, that is to say, to bring about something that was not there before. Literary objects (and more generally fictional objects) are a subtype of created objects. But the answer to the question "why write?" is not simply to be traced back to a creative drive. Rather, a complete answer to this question requires us to consider how we experience the objects we create. The products of our creative activity are never given to us as objects in the strict sense; they withdraw from objectivation precisely because they are the products of our spontaneous activity. One cannot at the same time unveil and create: "The creation becomes inessential in relation to the activity." 34 And one cannot react with surprise before works they have created and realize that they are the creator, since this would imply that one already sees one's own work with the eyes of another. Thus, what prevents us from grasping the product as an object is precisely the consciousness of our spontaneous and creative activity. From the first-person perspective, what one finds in one's productions is again a product of one's spontaneous activity:

But if we ourselves produce the rules of production, the measures, the criteria, and if our creative drive comes from the depth of our heart, then we never find anything but ourselves in our work. It is we who have invented the laws by which we judge it. It is our history, our love, our gaiety that we recognize in it. Even if we should regard it without touching it any further, we never receive from it that gaiety or love. We put them into it. The results which we have obtained on canvas or paper never seem to us objective. We are too familiar with the processes of which they are the effects. These processes remain a subjective discovery; they are ourselves, our inspiration, our ruse, and when we seek to perceive our work, we create it again, we repeat mentally the operations which produced it; each of its aspects appears as a result. Thus, in the perception, the object is given as the essential thing and the subject as the inessential. The latter seeks essentiality in the creation and obtains it, but then it is the object which becomes the inessential. ${ }^{35}$

Sartre then concludes that literary and fictional objects cannot depend exclusively on the creative act of the producer. They can only exist in a dialectical movement, like a spinning top: In order to make it appear "a concrete act called reading is necessary, and it [the literary object, author's note] lasts only as long as this act can last. Beyond that, there are only black marks on paper." 36 Sartre's formulation of the need to take into account the activity of reading within the constitution of fictional entities is certainly to some extent problematic. In fact, one could think that fictional entities would be in this sense reducible to their being imagined or thought about. This, as Amy Thomasson remarks, ${ }^{37}$ is not the case: We can speak of Faust as a fictional entity — and as existing as a fictional entity—without being engaged in the reading of the play. Sartre's actualism, in other words, risks turning into a kind of

\footnotetext{
34 Sartre (1966, p. 39).

35 Sartre (1966, p. 40).

36 Sartre (1966, pp. 40-41).

37 Thomasson (2008, pp. 21 f.).
} 
phenomenalism. Yet, independently of this problematic assumption, it is clear that Sartre wants to emphasize that besides the drive to create, there is a drive to produce something objective, that is, something that is accessible to and recognized by others. In this sense, every written production is for Sartre a social act.

Even without developing a detailed stratified ontology as Ingarden does, Sartre would agree that the existence of fictional entities is based on dependence relations, including linguistic sound formations, meaning units, and the reference to objects through schematized aspects. Yet, he mostly insists on another, connected, dependence relation: the dependence on the constituting activity of both producer and reader. And he considers the "conjoint effort of author and reader" ${ }^{38}$ in terms of an objectivation based on dialectical negation.

Sartre's discussion of how literary objects properly become objects, in fact, recalls several aspects of the structure of the look and being-for-others in Being and Nothingness. ${ }^{39}$ It is only through the look of the other, and by imagining how the other sees me, that I am aware of myself as an object, that is, as an object for others. ${ }^{40}$ Analogously, the subjective expressions of my own feelings and thoughts in my writing are not and cannot become an object for me if I consider them only from my individual, first-person point view. I can only become aware of them as object by means of a specific movement of negation actualized by the view others have on what I write. Only through such a movement I become aware of products of my spontaneity as objects in the public sphere: They can be seen, named, interpreted, used by others, and so on. Accordingly, assuming that one only writes for oneself is contradictory. Even after some time, and even if one may assume an external point of view or partly interiorize the others' look, one would always see oneself - maybe with some form of estrangement-in one's own productions. I will always have a unique access to my own productions, and this access substantially differs from the one that others have to my work. For this reason, as Sartre remarks:

The creative act is only an incomplete and abstract moment in the production of a work. If the author existed alone, he would be able to write as much as he liked; the work as object would never see the light of day and he would either have to put down his pen or despair. ${ }^{41}$

This common effort of authors and readers is not just a matter of a joint activity, precisely because it is understood as a dialectical movement. On the one hand, the activity of readers in a specific sense negates the spontaneity of the productive and spontaneous imaginative activity of writers. On the other hand, writers also negate or limits the spontaneous activity of readers by prescribing what they have to

\footnotetext{
${ }^{38}$ Sartre (1966, p. 43).

${ }^{39}$ Sartre (2003, pp. 340 f.).

${ }^{40}$ On the controversial issue of whether and how imagination plays a role in this process, see Bonnemann (2018).

${ }^{41}$ Sartre (1966, p. 42).
} 
imagine. Understood in these terms, the cooperative-dialectical enterprise justifies Sartre's claim " $[\mathrm{t}]$ here is no art except for and by others." 42

\section{The performative character of fictional works: The appellative structure}

How are the previous remarks on the ontology and constitution of fictional objects connected to the pragmatics of language in fictional, and particularly in literary, works?

First of all, we should recognize that literary works, taken as complexes of linguistic utterances, do not have the typical structures of performative utterances. Apparently, a novel does not promise, bet, command, or similar. This is probably one of the reasons behind the different understanding of questions concerning the pragmatics of fictional language I have taken into account above. In this section, I wish to show in what sense the constitutive indeterminacy and incompleteness of fictional objects require us to consider fictional language-or the fundamental layer in the constitution of fictional objects - as performative or as having, besides a locutionary, also an illocutionary and a perlocutionary aspect. This discussion relies on the phenomenological analysis of the actions of writing and reading and correspondingly on the relationship between writer and reader.

The pragmatics of fictional language does not seem to represent a major issue for Ingarden. ${ }^{43}$ The sections of The Literary Work of Art devoted to the linguistic sound formations and to the meaning units delve into to the clarification of how meaning is constituted on the basis of the material layer of the linguistic formations (Wortlaut). The focus thereby is on semantics and the phenomenological theory of meaning. ${ }^{44}$ Yet, while taking up several aspects of Ingarden's theory of the literary work of art, and partly criticizing the lack of explicit considerations regarding the pragmatics of language, Iser argues that Ingarden's stratified ontology and epistemology of the

\footnotetext{
42 Sartre (1966, p. 43).

43 In 1958, Ingarden writes a text entitled "The Functions of Language in the Theatre" (now published as appendix to The Literary Work of Art, Ingarden 1973b, pp. 377-396), in which he addresses the usage of language in both theatrical pieces and in their performance on stage. In general, Ingarden considers theatrical representation as a form of concretization of the literary work, which however reproduces the structure as a work of fiction, thus opening up to further concretizations by the public. While taking the theater script as a text based on a main text (i.e., the properly fictional work) and also containing stage directions, which as commands have a performative function, Ingarden focuses on the functions of language in the main text. In this regard, taking up Karl Bühler's distinctions concerning the functions of language, Ingarden argues that the theatrical text, particularly in its staging, has four functions: representation, expression, communication, and action. His remarks on the last function clearly recall performative analyses of language. However, Ingarden's main questions are closer to those addressed by Austin with regard to the performative function within the play itself (i.e., the fictional effect that speech acts have within the fictional work) and to those addressed by Currie with regard to the illocutionary and perlocutionary function considered with respect to the real audience in the theater. In this section, I will try to show how Ingarden's analyses also allow us to reassess the performative character of literary language (and not only of theatrical plays and performances) on another level.

44 Ingarden (1973b, pp. 34 f., 62 f.).
} 
literary work in fact requires a pragmatic approach to language. ${ }^{45}$ The pragmatic dimension of fictional language is not separable from the semantic one, and only if we jointly consider these dimensions, can we understand the interaction between author and reader. Iser's main assumption is that we cannot reduce the meaning of a fictional work to something pre-existing and independent of the text itself. Any attempt to interpret a fictional text as "the illustration of a meaning that precedes it," be that as "expression of neurosis of the author" or as the "mirroring of social states," is an oversimplification. ${ }^{46}$ In fact, none of these interpretations can explain why readers get involved in an epoch or a situation they are not actually part of. In order to clarify this phenomenon, it is necessary to investigate how readers, on the basis of the possibilities opened up by the text, actualize the work of fiction as to make it present and concrete in a specific way.

Against this background, Iser connects Ingarden's phenomenology of the literary work-and most importantly his remarks on the constitutive undeterminable indeterminacy characterizing fictional objects and the need to fill the gaps in the fictional work by means of concretization - with Austin's speech-act theory. ${ }^{47}$ In reference to Austin's distinction between constative and performative utterances, Iser maintains that, if we admit that literary works do not express any independently subsisting meaning and that they do not have any objectual correlate as something that already exists in the real world, then we should consider how they "produce their objects on the basis of elements that are to be found in the life-world." ${ }^{48}$

One aspect connecting literary expressions to performatives is therefore their productive nature: while being formulated, these expressions $d o$ something, namely produce or create something that was not there before. ${ }^{49}$ Furthermore, Iser adds two more points to his account of the particular productive power of fictional language. First, granted that fictional language has a performative or productive character, we should recognize that what is produced by utterances formulated in a fictional context cannot be confused with what is produced in a real context. What a literary text produces is fiction..$^{50}$ Secondly, and relatedly, the felicity conditions for fictional language should not be confused with the felicity conditions underlying the success or failure of real speech acts. On the basis of these two restrictions, Iser understands the specific performative character of fictional language as related to its typical "de-pragmatizing" nature (Entpragmatisierung) $)^{51}$ While echoing Ingarden's claim concerning a "habit of reality" (Realitätshabitus) ${ }^{52}$ at work in the process of

\footnotetext{
45 Iser (1975a, b, 1984).

46 Iser (1975b, pp. 230-231).

47 Iser (1984, pp. 89 f.).

48 Iser (1975b, pp. 231).

49 Cf. Genette (2004).

50 Iser (1975b, p. 231).

51 Iser (1984, pp. 100 f.).

52 Ingarden (1973b, pp. 220 f.). The habit of reality concerns the way objects are imagined and gaps are filled: What readers unreflectively do when reading a text, is to fulfill the gaps primarily in a way that mirrors what they are accustomed to in reality, and to connect this with the framework defined by the text itself.
} 
concretization and in the filling the gaps of fictional works, Iser argues that we tend to concretize fictions in a way that is familiar to us from our real experience. Yet, he also remarks that, in processes of concretization, we constitute "a world that is only apparently familiar to us, in a way that departs from what we are accustomed to."53 Such a departing is not a mere matter of degree of similarity; instead, it derives from a substantial or categorial difference between our experience of real objects as belonging to a network of pragmatic relations and the de-pragmatized character of fictional objects. Accordingly, besides highlighting the constitutive incompleteness of fictional entities, Iser endorses Kant's claim concerning the disinterested character of aesthetic experience. Literary works are not appreciated on the basis of their utility or of any pragmatically or even ethically relevant value. Instead, they reproduce contexts and situations that in real life would touch us due to their pragmatic (or even ethical and existential) value and precisely bracket any interest in such value. However, if this is the case, can we still speak of a proper performative function of fictional language? If this function is to be taken as belonging to the pragmatics of language, isn't there something contradictory in the claim that such a function is related to the de-pragmatizing nature of fiction?

Iser understands the performative nature of literary texts as an appellative structure. In one sense, such an appellative structure, which he also calls an "offer to participate" (Beteiligungsangebot) in the text, ${ }^{54}$ is related to the constitutive indeterminacy of fictional works. Accordingly, such works are appeals to readers, asking them to activate their imagination, to fill in, implicitly or explicitly, part of the indeterminacies in the texts. Rather than being a deficiency, thus, the indeterminacy of fiction is what underpins the productivity of fictional language. This is however only one side of the appeal. Iser also stresses that what is produced in and through such concretizing processes are not only the fictional objects and the fictional world, but also a new perspective and new insights on the real world. ${ }^{55}$ Besides being an appeal to co-constitute fictional objects, the speech act of the writer is an invitation for us to de-center ourselves, to detach from the immediateness of our experience of reality while imagining and co-constituting other realities. As a reverberation of this process, readers will also be able to take a new perspective on the real and familiar world. ${ }^{56}$ Although this may initially sound paradoxical, this latter effect of reading fictional works is precisely to be understood as a consequence of the de-pragmatizing function, and of the activation of our imaginative activity. While filling in the gaps and thus cooperating in the production of the fiction, the imaginative activity opens up new perspectives, allowing us to vary our perspective on reality. Also, even if they are detached from real pragmatic concerns, what we find in literary and generally fictional works are stories related to situations, characters, emotions, values that are meaningful to us in real life. And such stories can have educative effects on our real life; they refine our sensibility for what happens in the world and may

\footnotetext{
53 Iser (1975b, p. 232).

54 Iser (1975b, p. 235)

55 Iser (1975b, p. 232)

56 Iser (1975b, p. 233)
} 
motivate us to act accordingly. All this can be achieved if we follow the appeal to imagine, to abstract from real pragmatic concerns, to take distance from what we immediately experience, and to shift perspective.

Such an appellative function can be expressed in many ways in and through the text. In particular, Iser argues that it is entailed in such aspects as descriptions, montage, and in particular narrative interventions such as that of the commentator. The latter is what we can call a meta-fictional voice, or a voice which, within the fiction, takes a stance and comments on the fiction, for instance evaluating, formulating hypotheses, or expressing irony. ${ }^{57}$ In this way, the text offers "provocations to our capacity to judge" 58 that go beyond the domain of fictionality and set up a bridge to the real, which reinforces the above-mentioned perspectival shift. The reader's response to the appeal of the literary work can thus oscillate between normalizing attitudes - taking up features of reality in order to fill in the gaps of the fiction, but possibly leaving the assumed sense of reality and its normative structures untouched - and a transformative attitude, which we assume if we take the detour through the fiction as an appeal to change something in our real world, or at least in the way we look at the real world. ${ }^{59}$

For Sartre as well, the ontology of fictional objects correlates with the pragmatics of language. In fact, as he aims to clarify the meaning of the expression "engaged literature," he intently investigates the transformative, practical, and also political implications of literary language. Much more than Iser and Ingarden, Sartre is particularly interested in the interconnection between the aesthetics of literature and the ethical/political implications of the pragmatics of fictional language. These implications are developed on the basis of several remarks concerning what language, and notably literary language, does. Two main claims in Sartre's What is Literature? exemplify this development. These claims are: (a) that both writing and reading are to be considered as actions, and (b) that literary texts have a specific appellative structure.

(a) Sartre criticizes the claim that literary texts should be considered as merely describing or testifying something. According to this interpretation, a literary work would be like zephyr: it would only slightly pass on the surface of things, without compromising anything. ${ }^{60}$ Thus, writing would be the harmless expression of a supposedly disinterested contemplation. Sartre maintains instead that, although literary works do not have-at least prima facie - the structure of standard performative utterances, we cannot reduce them to mere descriptions. Even the descriptive parts cannot be considered independently of broadly conceived performative implications. Sartre's critique to the descriptive assumption is based on the idea that every speech act is an action:

\footnotetext{
57 On the role of the commentator and of meta-fictional statements in the so-called phenomenon of imaginative resistance, see Summa (forthcoming).

58 Iser (1975b, p. 239).

59 Iser (1975a, b).

60 Sartre (1966, p. 22).
} 
To speak is to act; anything which one names is already no longer quite the same; it has lost its innocence. If you name the behavior of an individual, you reveal it to him; he sees himself. And since you are at the same time naming it to all others, he knows that he is seen at the moment he sees himself. The furtive gesture which he forgot while making it, begins to exist beyond all measure, to exist for everybody; it is integrated into the objective mind (esprit objectif); it takes new dimensions; it is retrieved."61

Even more than speaking, writing is an action. In fact, writing is a much more pondered and exposed form of linguistic expression: Writing means at the same time externalizing and shaping one's own thought, taking a position on what one experiences and-since the product of writing is not bound to the present situation as speaking is-delivering such an expression and such position-taking to a potentially larger audience. Also, as we saw, through writing one implicitly agrees that one's own thought gets exposed to the look of others, and in such a way it reaches a kind of objectivation that unexpressed thinking never has. Importantly, transposing one's own thoughts in the public sphere also means taking responsibility both for what one says and writes and for what one does not say and write. ${ }^{62}$

The action that one does by writing is at the same time the unveiling or disclosing (dévoilement) of something-historical situations, events, human and social relationships, etc.- - and a transformation concerning what is unveiled and, prospectively, also the way readers will face reality. The two actions are so entwined that Sartre can claim that the prosaist is someone "who has chosen a certain method of secondary action which we may call action by disclosure." ${ }^{63}$ Also, while emphasizing the conscious character of this action, Sartre remarks that the engaged writer knows that words are actions and that "to reveal is to change and that one can reveal only by projecting to change." 64

Considering the pragmatics of fictional language, it can be argued that the intertwining between transforming and unveiling or disclosing —or the idea that writing is transforming by means of disclosing-somehow mirrors the interplay between the locutionary and illocutionary dimensions of speech acts. Even if the text may only be describing, an action is accomplished. This action, for Sartre, begins with the decision to write, that is to say, to expose one's own thoughts to the public sphere; it then continues with the decision concerning the topic about which to write, the aspects one writes or does not write about, the style to adopt, the different literary devices to employ, etc. One can certainly object at this stage that Sartre's approach puts too much emphasis on conscious decision making, without considering that, even if writing is a highly reflected activity, there are aspects of the action that, like in all other actions, are implicitly operative and potentially escape the writer's

\footnotetext{
61 Sartre (1966, p. 22).

62 Sartre (1966, pp. 24 f.)

63 Sartre (1966, p. 23).

64 Sartre (1966, p. 23).
} 
self-consciousness. Yet, Sartre seems exactly to recognize this by taking into account the action of reading as necessarily complementary to the action of writing.

Indeed, the action of writing is actually not accomplished until a complementary action, that of reading, is also executed. In part, this claim results from the dialectics in the constitution of the fictional object; in part, however, it can also be read as indicating that, like other performative and social acts, the act of writing is in need of uptake. ${ }^{65}$ And this brings us now to the appellative nature of texts and relatedly, for Sartre, to the sociality of fictional language.

(b) Like Iser, Sartre also understands the literary text as appeal to the reader. What the two authors share, then, is primarily the idea that reading is not just a receptive - and certainly not a passive-phenomenon. Instead, reading is an action, required both in order to constitute the fictional object and in order to complete the action initiated by the author's writing. The main differences between Iser's and Sartre's approaches to the act of reading concern, for one, the dialectical component in Sartre's account, which Iser does not take up. Furthermore, Sartre's emphasis on engagement implies a rejection of Iser's idea of de-pragmatizing the experience of art, or at least of prose. Sartre's position concerning the latter point, I believe, should not be understood as suggesting that art should be in the service of something else, notably a pre-defined ideology. If we take Sartre's observations on the act of reading as a conscious response to the appeal of the text, we can in fact find elements in support of a critical and enlightened understanding of the reader's activity. In and through the act of reading, the readers make choices, they take responsibility for their following the text, filling its gaps, and somehow appropriating it by developing an autonomous interpretation. Like the act of writing, the act of reading also entails moments of unveiling or disclosing and creating. The unveiling, however, is not primarily related to something given in the world, which is named and thus shaped as such in the text. Rather, the unveiling activity of the reader is related to the text itself: It is the unfolding of the look, which makes the objectivation of the fictional entities and the fictional world possible. Taken as an activity of unveiling, the act of reading comes close to the act of perceiving: Reading is a way of being affected by, receiving, disclosing, and grasping what is drafted in the text, like perceiving is a way of being affected by, receiving, disclosing, and grasping what is given in the world. In this sense, the text somehow prescribes ways of appropriate reading, or appropriate imagining of what one reads. Or at least it sets the limits for what one can possibly imagine.

The creative moment derives from the fact that, due to the constitutive incompleteness of the writer's activity, the normativity of the text is not fixed once and for all. Thus, the reader is called to actively participate, by means of an external look, in the constitution of the fictional world. Yet, the activity of reading also underlies new possibilities for acting in the real world. And here, besides the differences, we can find some affinities with Iser and possibly also some explication of what remains implicit in his position. After all, claiming that reading a fictional work allows us to develop a new perspective on the real world also implies that our possibilities to act

\footnotetext{
65 Austin (1962, pp. 108 f.) and Mulligan (1987).
} 
in the real world, the range of choices we can make as well as the perspectives we are able to take, are developed and extended.

All this is accomplished by the reader in and through a kind of dialectical interaction with the text and, through the text, with the author. The just mentioned perspectival shift and turn to irreality do not occur, like in the imaginary, on the basis of a solitary act of negation. Rather, they occur on the basis of the appellative and somehow even prescriptive character of the written text, as a project that the reader has not spontaneously made or chosen, inasmuch as it is the result of someone else's spontaneous activity. In the act of reading, the receptive and the productive moment are interdependent. And, for this reason, the effectiveness of a literary text is based on a social act, which derives from the appellative structure of the text. This act is a "pact of generosity" 66 between authors and readers:

As the sufficient reason for the appearance of the aesthetic object is never found either in the book (where we find merely solicitations to produce the object) or in the author's mind, and as his subjectivity, which he cannot get away from, cannot give a reason for the act of leading into objectivity, the appearance of the work of art is a new event which cannot be explained by anterior data. And since this directed creation is an absolute beginning, it is therefore brought about by the freedom of the reader, and by what is purest in that freedom. Thus, the writer appeals to the reader's freedom to collaborate in the production of his work. ${ }^{67}$

The choice of dedication and the generosity of the reader consist first of all in following the prescriptions to imagining entailed in the text, taking them up and at the same time developing a new, singular, and yet still autonomous perspective on the object itself. The result is the accomplishment of the author's project, which is renewed in every moment of reading. Responding to the appeal of the text means in this sense looking at it from an external point, and in such a way making it objective; furthermore, it means developing it in ways that may not have been predicted by the author and using the insights to enrich our ability to understand the real world and responsibly act, or engage, in it.

\section{Conclusions}

The aim of this article was to shed light on the connection between the ontology of fiction and the pragmatics of fictional language. The ontological approach to fiction I have defended is based on observations concerning the intentional nature, the indeterminacy, and the incompleteness of fictional objects, which can be considered as existent only on the basis of dependency relations. Both Ingarden and Sartre stress these ontological features of fictional objects. I have argued that these ontological approaches to fictional entities need to be grounded on the pragmatics of fictional

$\begin{array}{ll}{ }^{66} & \text { Sartre (1966, p. 55). } \\ 67 & \text { Sartre (1966, p. 46). }\end{array}$ 
language and on the cooperation between authors and readers. Such a performative dimension is not sufficiently explored if we limit ourselves to consider either the status of singular utterances in the fiction or the fact that the author of a work of fiction formulates only pretend speech acts.

Discussing the work of Ingarden, Iser, and Sartre, I have argued that, when we engage with fiction, we are certainly doing something unseriously or playfully, in other words, something detached from reality. Yet, this is only one side of the story. If we more closely consider our participation in fiction, both as authors and as readers, we should in fact recognize that we actually also do something serious, genuine, and something that has a concrete impact on reality.

Expanding on these analyses, we can say that the perlocutionary and the illocutionary functions are interconnected in the appellative act produced in and through fictional discourse. In particular, literary works, considered from this perspective, are appeals, demands, intimations, or invitations to readers. They invite readers to follow the outline of the text, to fulfill the gaps and to add layers of objectivation that cannot be in principle produced by authors alone. A reader's response is an active one. It is a choice of following the other in the figure of the author and the text itself and of maintaining autonomy and productive potential precisely while making this choice. This is, however, not limited to the experience of fiction. Rather, in a more encompassing sense, fictional works are appeals to real transformations, to be realized by means of a re-shaping of one's own world view and of acting consequently. This is a transformative turn to reality that can only be accomplished in and through a socially structured imaginative detachment or negation of reality.

Open Access This article is licensed under a Creative Commons Attribution 4.0 International License, which permits use, sharing, adaptation, distribution and reproduction in any medium or format, as long as you give appropriate credit to the original author(s) and the source, provide a link to the Creative Commons licence, and indicate if changes were made. The images or other third party material in this article are included in the article's Creative Commons licence, unless indicated otherwise in a credit line to the material. If material is not included in the article's Creative Commons licence and your intended use is not permitted by statutory regulation or exceeds the permitted use, you will need to obtain permission directly from the copyright holder. To view a copy of this licence, visit http://creativecommons.org/licen ses/by/4.0/.

\section{References}

Austin, J.L. 1962. How to Do Things with Words. Oxford: Clarendon Press.

Austin, J.L. 1970. Performative Utterances. In Philosophical Papers, ed. J.O. Urmson and G.J. Warnock, 233-252. Oxford: Oxford University Press.

Bonnemann, J. 2007. Der Spielraum des Imaginären. Hamburg: Meiner.

Bonnemann, J. 2018. Sartre and the Role of Imagination in Mutual Understanding. In Imagination and Social Perspectives. Approaches from Phenomenology and Psychopathology, ed. M. Summa, T. Fuchs, and L. Vanzago, 155-166. London: Routledge.

Currie, G. 1986. Works of Fiction and Illocutionary Acts. Philosophy and Literature 10 (2): 304-308.

Currie, G. 1990. The Nature of Fiction. Cambridge: Cambridge University Press.

Genette, G. 2004. Les actes de fiction. Fiction et diction. Paris: Seuil. 
Husserl, E. 2005. Phantasy, Image Consciousness, and Memory (1898-1925). Translated by J.B. Brough. Dordrecht: Springer.

Ingarden, Roman. 1973a. The Cognition of the Literary Work of Art. Translated by R.A. Crowley and K.R. Olson. Evanston: Northwestern University Press.

Ingarden, Roman. 1973b. The Literary Work of Art. Translated by G. G. Grabowicz. Evanston: Northwestern University Press.

Iser, W. 1975a. Der Lesevorgang. In Rezeptionsästhetik. Theorie und Praxis, ed. R. Warning, 253-276. München: Fink.

Iser, W. 1975b. Die Appellstruktur der Texte. Unbestimmtheit als Wirkungsbedingung literarischer Prosa. In Rezeptionsästhetik. Theorie und Praxis, ed. R. Warning, 228-252. München: Fink.

Iser, W. 1984. Der Akt des Lesens. Theorie ästhetischer Wirkung. München: Fink.

Kroon, F., \& Voltolini, A. (2018) Fictional Entities. In The Stanford Encyclopedia of Philosophy, ed. E.N. Zalta. https://plato.stanford.edu/archives/win2018/entries/fictional-entities/. Accessed 17 May 2019.

Lewis, D. 1978. Truth in fiction. American Philosophical Quarterly 15 (1): 37-46.

Locher, M.A., and A.H. Jucker (eds.). 2017. Pragmatics of Fiction. Berlin: De Gruyter.

Meinong, A. 1904. Über Gegenstandtheorie. Untersuchungen zur Gegenstandtheorie und Psychologie. 1-50. Leipzig: Barth.

Mulligan, K. 1987. Promisings and Other Social Acts: Their Constituents and Structure. In Speech Act and Sachverhalt. Reinach and the Foundations of Realist Phenomenology, ed. K. Mulligan, 29-90. Dordrecht: Martinus Nijhoff.

Pratt, M.L. 1977. Toward a Speech Act Theory of Literary Discourse. Bloomington/London: Indiana University Press.

Recanati, F. 2000. Oratio Obliqua, Oratio Recta. Cambridge, MA: MIT Press.

Ryle, G. 2009. The Concept of Mind. London: Routledge.

Sartre, J.-P. 1966. What is Literature? Translated by B. Frechtman. New York: Philosophical Library.

Sartre, J.-P. 2003. Being and Nothingness. Translated by H. E. Barnes. London: Routledge.

Sartre, J.-P. 2004. The Imaginary. A Philosophical Psychology of the Imagination. Translated by J. Webber. New York: Routledge.

Searle, J.R. 1975. The Logical Status of Fictional Discourse. New Literary History 6 (2): 319-332.

Summa, M. 2019. Are Fictional Emotions Genuine and Rational? Phenomenological Reflections on a Controversial Question. The New Yearbook for Phenomenology and Phenomenological Philosophy 17: 246-267.

Summa, M. forthcoming. Imaginative Resistance and Self-Experience in Fiction. In Phenomenology of Phantasy and Emotions, eds. T. Breyer, M. Cavallaro and R.Y. Sandoval. Bern: Peter Lang.

Thomasson, A. 2008. Fiction and Metaphysics. Cambridge: Cambridge University Press.

Walton, K. 1983. Fiction, Fiction-Making, and Styles of Fictionality. Philosophy and Literature 7 (1): 78-88.

Walton, K. 1990. Mimesis as Make-Believe. On the Foundations of the Representational Arts. Cambridge MA: Harvard University Press.

Publisher's Note Springer Nature remains neutral with regard to jurisdictional claims in published maps and institutional affiliations. 